\title{
Linear immunoglobulin A (IgA) bullous dermatosis
}

\author{
*K Rajendran ${ }^{1}$, Abhijit Anil Patil ${ }^{1}$ \\ Sri Lanka Journal of Child Health, 2018; 47: 271-272 \\ DOI: http://dx.doi.org/10.4038/sljch.v47i3.8552 \\ (Keywords: Linear IgA dermatosis, immunofluorescence, dapsone)
}

\section{Introduction}

Linear immunoglobulin A ( $\operatorname{IgA})$ bullous dermatosis (LABD), first described by Bowen in 1901, is an autoimmune disease occurring in both children and adults ${ }^{1,2}$. Around two thirds of cases are induced by antibiotics, nonsteroidal anti-inflammatory agents and diuretics ${ }^{2}$. Childhood LABD is synonymous with chronic bullous disease of childhood (CBDC) $)^{3}$.

\section{Case report}

A 3 year old boy presented with blisters all over the body, more over the lower limbs, upper limbs and ear lobes, since 10 days associated with severe itching and mild pain (Figure 1).

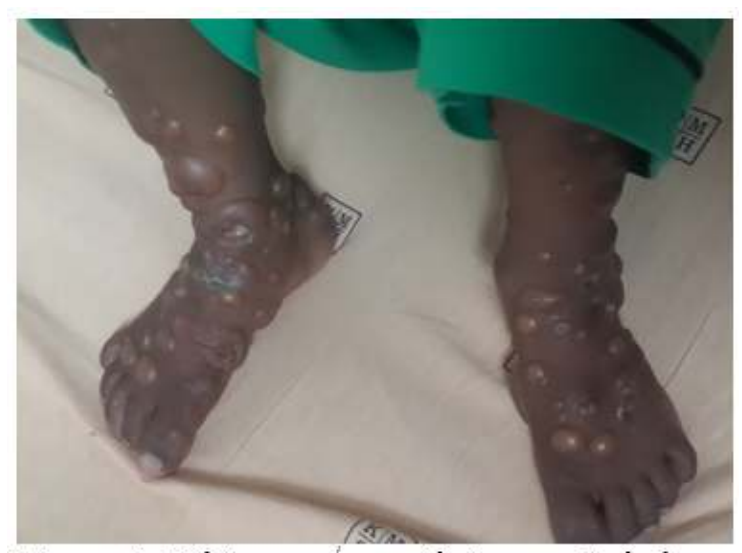

Figure 1: Blisters on lower limbs on admission

Ruptured blisters were also present. There was no history of fever. The blisters started as small papules on the lower limbs and spread all over the body.

Total white blood cell count was 11,200/cu mm (24\% polymorphs, 50\% lymphocytes, $24 \%$ eosinophils, 2\% monocytes). Erythrocyte sedimentation rate was $8 \mathrm{~mm}$ in the first hour,

${ }^{1}$ Department of Paediatrics, Kovai Medical Centre and Hospital, Coimbatore, Tamil Nadu, India

*Correspondence: drrajendrantk@gmail.com

(Received on 02 January 2017: Accepted after revision on 20 February 2017)

The authors declare that there are no conflicts of interest

Personal funding was used for the project.

Open Access Article published under the Creative

Commons Attribution CC-BY (c) (i) the haemoglobin $(\mathrm{Hb})$ level $12.7 \mathrm{~g} / \mathrm{dl}$ and the platelet count 458,000/cu mm. Serum immunoglobulin E (IgE) level was $112.4 \mathrm{IU} / \mathrm{ml}$ (normal up to 60 $\mathrm{IU} / \mathrm{ml}$ ), serum immunoglobulin A (IgA) level 72 $\mathrm{mg} / \mathrm{dl}$ (normal 19-220 $\mathrm{mg} / \mathrm{dl}$ ), serum immunoglobulin M (IgM) level $167 \mathrm{mg} / \mathrm{dl}$ (normal $40-180 \mathrm{mg} / \mathrm{dl}$ ) and the serum immunoglobulin G (IgG) level $800 \mathrm{mg} / \mathrm{dl}$ (normal 500-1300 mg/dl). The gram stain of blister fluid showed a few pus cells but no organisms. Skin biopsy taken from the leg was consistent with linear IgA bullous dermatosis. Direct immunofluorescence showed a linear basement membrane zone band with IgA, confirming linear IgA disease. Glucose-6-phosphate-dehydrogenase (G6PD) level was 11 units/g Hb (normal range 4.613.5 units $/ \mathrm{g} \mathrm{Hb}$ ). He was successfully treated with intravenous methylprednisolone $(1.5 \mathrm{mg} / \mathrm{kg} /$ day $)$ for 5 days followed by oral steroid $(1 \mathrm{mg} / \mathrm{kg})$ and oral dapsone $(1 \mathrm{mg} / \mathrm{kg})$. He is on regular follow up and his skin lesions have improved (Figure 2).

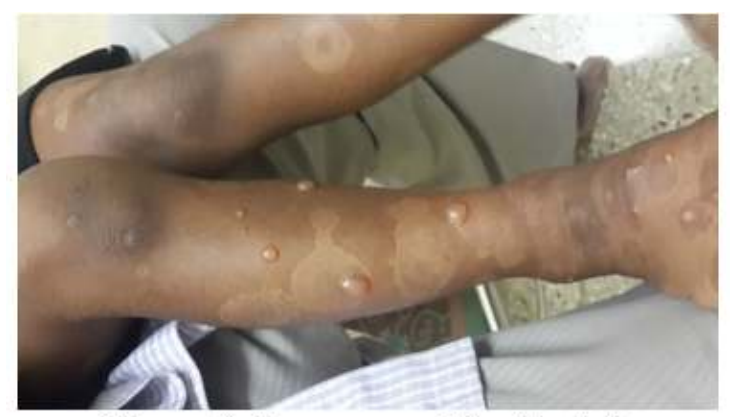

Figure 2: Improvement in skin lesions

\section{Discussion}

Prevalence of LABD in children is unknown. Age of onset in children ranges from 1 to 10 years $^{4}$. Our patient was 3 years old. Childhood LABD has rarely been associated with ulcerative colitis and autoimmune lymphoproliferative disease ${ }^{5,6}$. LAPD characteristically has linear IgA deposits in the basement membrane zone of the skin, circulating basement membrane zone antibodies being detected in over $80 \%$ of patients ${ }^{3}$. Our patient showed a linear basement membrane zone band with $\operatorname{IgA}$ on immunofluorescence. How drugs stimulate the immune system to produce IgA antibodies against the basement membrane in LABD is still unknown ${ }^{5}$. Both idiopathic and drug-induced LABD can be triggered by physical trauma, burns, or infections ${ }^{3}$. There were no triggering factors noted in our case. Typically, there is an interval of 2 to 28 days between the drug involved and the bullous eruption ${ }^{2}$. 
Lesions of drug-induced LABD resolve spontaneously within 2 to 7 weeks following withdrawal of the drug. No drug was incriminated in our patient. In a study by Wojnarowska $\mathrm{F}$, et al. of 25 cases of childhood LABD, 64\% remitted within 2 years and only in $12 \%$ was the disease active after puberty $^{8}$. The treatment of choice in LABD is dapsone alone or in combination with systemic steroids $^{9,10}$. Our patient was treated with dapsone and steroids. Dapsone may cause haemolysis in G6PD deficient individuals. In our patient the G6PD level was normal. Flucloxacillin may be considered as an alternative therapy ${ }^{11}$. In dapsone resistant cases, tacrolimus ointment may be beneficial ${ }^{12}$.

\section{References}

1. Bowen JT. Six cases of bullous dermatitis following vaccination, and resembling dermatitis herpetiformis. Journal of Cutaneous Disease 1901; 19: 401-23.

2. Ho JC, Ng PL, Tan SH, Giam YC. Childhood linear IgA bullous disease triggered by amoxicillin-clavulanic acid. Paediatric Dermatology 2007; 24(5): E40-3. https://doi.org/10.1111/j.15251470.2007.004 38.x

PMid: 17958778

3. Polat M, Lenk N, Kurekci E, Oztas P, Artuz F, Alli N. Chronic bullous disease of childhood in a patient with acute lymphoblastic leukemia: possible induction by a drug. American Journal of Clinical Dermatology 2007; 8(6): 389-91. https://doi.org/10.2165/00128071200708060 $-00010$

PMid: 18039023

4. Nantel-Battista M, Dhaybi RA, Hatami A, Marcoux D, DesRoches A, Kokta V. Childhood linear IgA bullous disease induced by trimethoprim-sulfamethoxazole. Journal of Dermatological Case Reports 2010; 4(3): 33-5.

https://doi.org/10.3315/jdcr.2010.1053

PMid: 21886746 PMCid: PMC3157814

5. Wong CS, Arkwright PD, Rieux-Laucat F, Cant AJ, Stevens RF, Judge MR. Childhood linear IgA disease in association with autoimmune lymphoproliferative syndrome. British Journal of Dermatology 2004; 150(3): 578-80.

https://doi.org/10.1111/j.13652133.2004.058

50.x

PMid: 15030346
6. Handley J, Shields M, Walsh M, Bingham A. Chronic bullous disease of childhood and ulcerative colitis. British Journal of Dermatology 1992; 127:67-8. https://doi.org/10.1111/j.13652133.1992.tb0 1256.x

7. Egan CA, Zone JJ. Linear IgA bullous dermatosis. International Journal of Dermatology 1999; 38:818-27. https://doi.org/10.1046/j.13654362.1999.008 13.x

8. Wojnarowska F, Marsden RA, Bhogal B, Black MM. Chronic bullous disease of childhood, childhood cicatricial pemphigoid, and linear $\operatorname{IgA}$ disease of adults. A comparative study demonstrating clinical and immunopathologic overlap. Journal of the American Academy of Dermatology 1988; 19(5 Pt 1): 792-805. https://doi.org/10.1016/S01909622(88)7023 $6-4$

9. Nanda A, Dvorak R, Al-Sabah H, Alsaleh QA. Linear IgA bullous disease of childhood: an experience from Kuwait. Pediatric Dermatology 2006; 23(5): 443-7. https://doi.org/10.1016/S01909622(88)7023 6-4 https://doi.org/10.1111/j.15251470.2006.002 79.x

PMid: 17014638

10. Monia K, Aida K, Amel K, Ines Z, Becima F, et al. () Linear IgA bullous dermatosis in Tunisian children: 31 cases. Indian Journal of Dermatology 2011; 56: 153-9.

PMid: 21716539 PMCid: PMC3108513

11. Alajlan A, Al-Khawajah M, Al-Sheikh O, AlSaif F, Al-Rasheed S, et al. Treatment of linear IgA bullous dermatosis of childhood with flucloxacillin. Journal of the American Academy of Dermatology 2006; 54: 652-6. https://doi.org/10.1016/j.jaad.2005.11.1102 PMid: 16546588

12. Dauendorffer JN, Mahé E, Saiag $P$. Tacrolimus ointment, an interesting adjunctive therapy for childhood linear IgA bullous dermatosis. Journal of the European Academy of Dermatology and Venereology 2008; 22(3): 364-5. https://doi.org/10.1111/j.14683083.2007.023 15.x

PMid: 18269605 